Matematikai Közlemények

IV. kötet, 2016

doi:10.20312/dim.2016.04

\title{
A Kepler-féle egyenlet és az affin transzformációk
}

\author{
Péntek Kálmán \\ NymE SEK TTMK Matematika és Fizikai Intézet \\ pentek.kalman@nyme.hu
}

Összefoglaló: A dolgozatban a klasszikus Kepler-egyenlet egy egyszerü geometriai bizonyítását mutatjuk be az affin transzformációk alkalmazásával.

\begin{abstract}
In the paper, we present a simple proof of the classical Kepler's Equation with the using of the affin transformations.
\end{abstract}

\section{Bevezetés}

1609-ben jelent meg Johannes Kepler (1571-1630) német matematikus és csillagász Astronomia nova c. korszakalkotó müve. Ebben a könyvben szerepel a később róla elnevezett bolygómozgási törvények közül az első kettő. A ma elsőként emlegetett törvény azt a tényt rögzíti, hogy a bolygók ellipszis alakú pályákon keringenek a Nap körül úgy, hogy e pályák közös gyújtópontjában a Nap áll. A második törvény a területi sebesség állandóságát mondja ki, vagyis azt, hogy a Naptól a vizsgált bolygóig húzott sugár a bolygó változó sebességü mozgása folytán úgy halad, hogy közben egyenlő nagyságú időtartamok alatt azonos nagyságú területeket súrol. Más szóval a súrolt terület arányos az eltelt idővel. E felismerés fontos következménye az volt, hogy a bolygók a Nap közelében gyorsabban, míg a Naptól távoli pályaíven lassabban mozognak. Fontos kérdés tehát az ellipszis pályán végighaladó bolygók esetén a mozgás időbeni lefolyása, vagyis annak ismerete, hogy az adott időpillanatban az égitest pályájának mely pontján tartózkodik.

Johannes Kepler bolygómozgási törvényeit Tycho de Brahe (1546-1601) dán csillagász észlelési és mérési eredményeinek gondos, közel 8 éven át tartó elemzésével ismerte fel. A pálya alakját számos lehetséges síkgörbe tanulmányozása után a Pergai Apollóniosz (Kr.e. 265 - Kr. e. 190) által részletesen vizsgált kúpszeletek között találta meg. A bolygók mozgásának időbeni lefolyását leíró egyenletet Kepler geometriai módszerek felhasználásával vezette le saját, második törvényének felhasználásával. A dolgozat ezen, később Kepleregyenlet néven elhíresült összefüggésnek az affin transzformációkra támaszkodó egyszerü geometriai bizonyítását mutatja be.

\section{A Kepler-egyenlet}

Tekintsük az $O$ szimmetria középpontú pályaellipszist, tartózkodjék a Nap a $P_{1}$ fókuszpontban, ezen ellipszis mentén $P_{1}$ körül keringő égitest a $t$ időpillanatban legyen a $P_{2}$ pontban. Jelölje $r=P_{1} P_{2}$ a Naptól az égitestig húzott rádiuszvektort, s tegyük fel, hogy a vizsgált égitest a $P$ pericentrum ponton a $\tau$ időpontban halad át. Rajzoljuk meg a pályaellipszis főkörét, majd állítsunk merőlegest a $P_{2}$ pontban az ellipszis nagytengelyére. 
Jelölje $M$ e merőleges nagytengellyel alkotott metszéspontját, $Q$ a fökörrel alkotott egyik metszéspontját (1. ábra).

A keringő $P_{2}$ égitest helyzetét minden $t$ időpontban egyértelmüen jellemzi a $v=P P_{1} P_{2} \Varangle$, amelyet valódi anomáliának nevezünk. A mozgás könnyebb tanulmányozása érdekében az $a=O Q$ fökör sugarának pillanatnyi helyzete is jól jellemzi a $P_{2}$ pont pillanatnyi helyzetét, hiszen a $Q$ pontból a pályaellipszis nagytengelyére bocsájtott merőleges ellipszisre eső merőleges vetülete éppen $P_{2}$. A $Q$ pont főkörön elfoglalt helyzetét megadja az $E=P O Q \Varangle$ szög, amelyet excentrikus anomáliának nevezünk. Célszerúen a $v$ és az $E$ szögeket egyaránt radiánban mérjük.

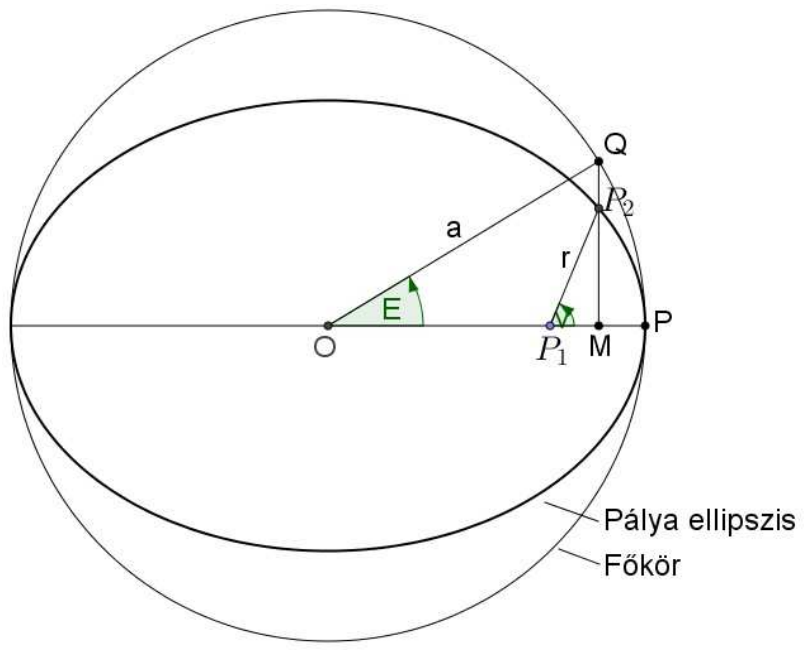

1. ábra. A v valódi anomália és az $E$ excentrikus anomália értelmezése

Feladatunk az ellipszisen végbemenő pályamenti mozgás időbeni leírása, tehát meghatározandó a $v=v(t)$ és az $E=E(t)$ függvénykapcsolat. Az ehhez szükséges geometriai ismereteket az alábbiakban foglaljuk össze.

Az affin transzformációk, vagy röviden affinitások, az euklideszi sík önmagára történő bijektív és egyenestartó leképezései. Az affinitások párhuzamosság-, osztóviszony- és területaránytartó leképezések, amelyeket egyértelmüen meghatároz 3 általános helyzetủ pont és affin képének megadása. Fontos típust képeznek e leképezések között a tengelyes affinitások, amelyeknél a tengely egyenese pontonként fix. Ekkor a pontokat a képükkel összekötő egyenesek párhuzamosak, amelyet a tengelyes affinitás irányának nevezünk. Ha ez merőleges a tengely irányára, ortogonális affinitásról beszélünk.

Legyen $t$ az affinitás tengelye, $P^{\prime}$ a $P$ pont ezen affinitás melletti képe, $P_{0}$ a $P P^{\prime}$ és $t$ metszéspontja, akkor a $P^{\prime} P_{0}: P P_{0}$ arány minden ilyen egymásnak megfelelő pontpár esetén azonos értékü lesz, amelyet a tengelyes affinitás arányának nevezünk. Az affin transzformációk részletes tárgyalását REIMAN [4] könyvében megtalálhatjuk.

Jelölje ezután $2 a$ a vizsgált pályaellipszis nagytengelyét, $2 b$ a kistengelyét és tekintsük azt az $\alpha$ tengelyes affinitást, amelynek tengelye az ellipszis nagytengelye, iránya az ellipszis kistengelye és aránya $b: a$. Ez a leképezés ellipszis fökörét pontosan az ellipszisre képezi le (2. ábra).

A pályaellipszis és fököre területaránya a fentiek szerint éppen az $\alpha$ affinitás aránya:

$$
\frac{t_{\circ}}{t_{\odot}}=\frac{b}{a}
$$

ahonnan az ellipszis területe:

$$
t_{\odot}=\frac{b}{a} \cdot t_{\odot}=\frac{b}{a} \cdot a^{2} \cdot \pi=a \cdot b \cdot \pi .
$$




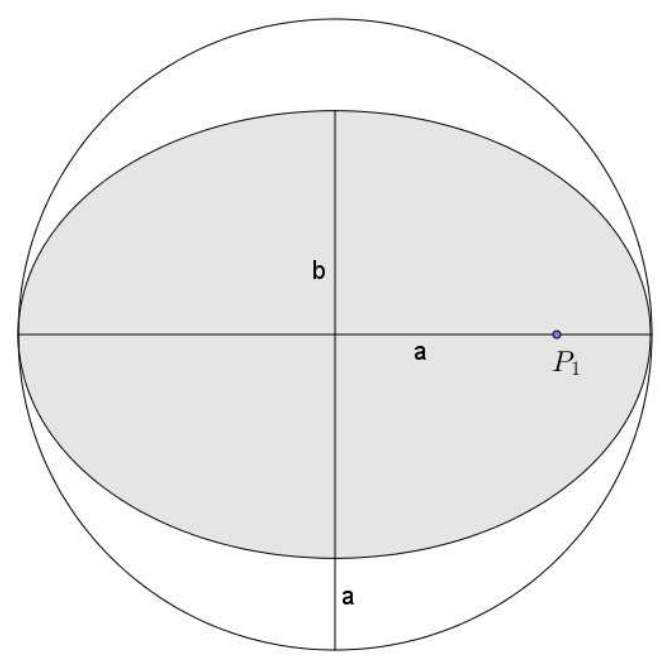

2. ábra. Az a sugarú főkör tengelyes affin képe a $2 a$ nagytengelyü és $2 b$ kistengelyü ellipszis

Tekintsük a pályaellipszis $P_{1} P P_{2}$ szektorát, amelynek területe Kepler II. törvénye szerint éppen úgy aránylik a teljes ellipszis területéhez, mint ahogyan a $P P_{2}$ ellipszis-ív befutásához szükséges $t$ - $\tau$ időtartam aránylik a keringő égitest teljes $T$ sziderikus keringési idejéhez:

$$
\frac{t_{P_{1} P P_{2}}}{t_{\circ}}=\frac{t-\tau}{T} .
$$

Feladatunk ezért a $P_{1} P P_{2}$ ellipszisszektor területének kiszámítása. Vegyük észre, hogy ezen $P_{1} P P_{2}$ ellipszisszektor éppen a $P_{1} P Q$ körszektor $\alpha$ tengelyes affinitás melletti képe, ezért a fentiek szerint

$$
\frac{t_{P_{1} P P_{2}}}{t_{P_{1} P Q}}=\frac{b}{a}
$$

teljesül, ahonnan átrendezéssel

$$
t_{P_{1} P P_{2}}=\frac{b}{a} \cdot t_{P_{1} P Q}
$$

adódik (3. ábra).

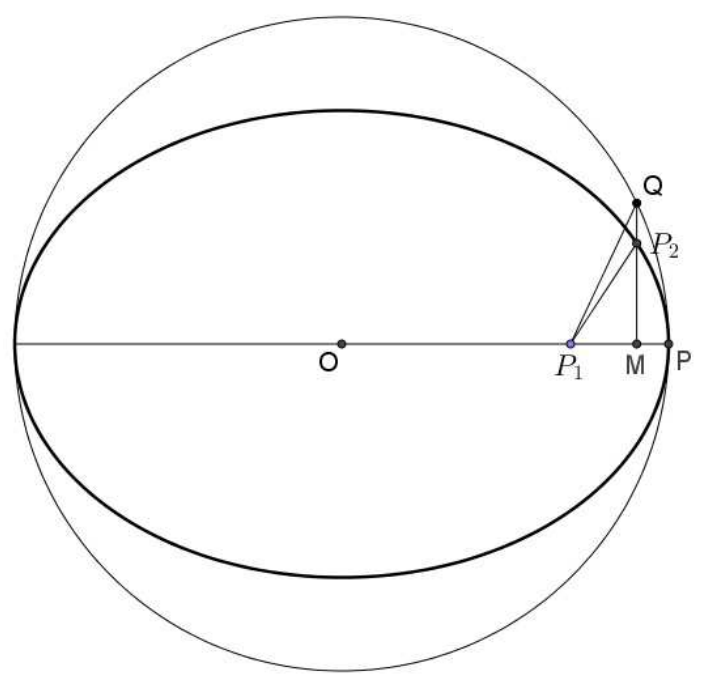

3. ábra. A $P_{1} P Q$ körszektor tengelyes affin képe a $P_{1} P P_{2}$ ellipszisszektor 
Figyeljük azonban meg, hogy a $P_{1} P Q$ körszektort előállíthatjuk, ha az $O P Q$ körcikkből elhagyjuk az $O P_{1} Q$ háromszöget, ezért fennáll a

$$
t_{P_{1} P Q}=t_{O P Q}-t_{O P_{1} Q}
$$

összefüggés (4. ábra).

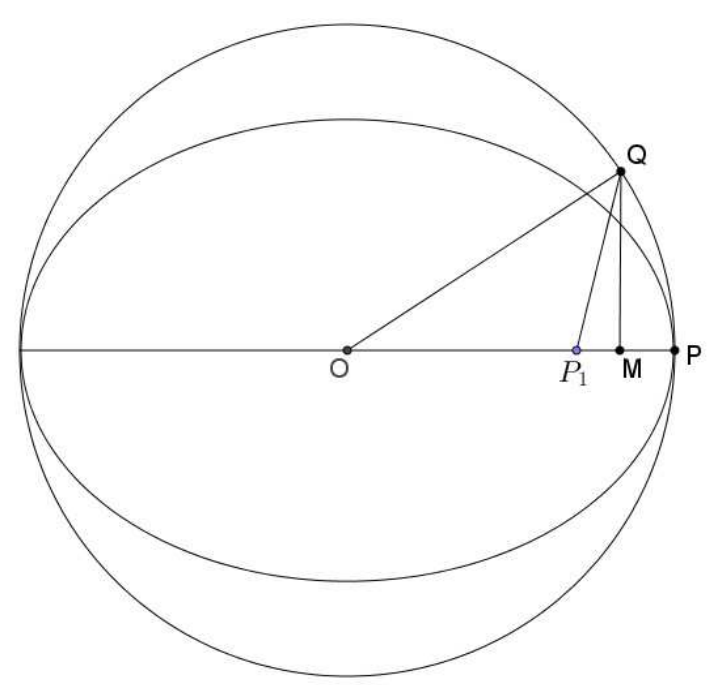

4. ábra. A $P_{1} P Q$ körszelet előállítása az $O P Q$ körcikk és az $O P_{1} Q$ háromszög segítségével

Az $O P Q$ körcikk területét viszont könnyen kaphatjuk, hiszen ennek értéke arányos lévén az $E$ szöggel:

$$
\frac{t_{O P Q}}{t_{\odot}}=\frac{E}{2 \pi},
$$

ahonnan közvetlenül

$$
t_{O P Q}=t_{\odot} \cdot \frac{E}{2 \pi}=a^{2} \cdot \pi \cdot \frac{E}{2 \pi}=\frac{1}{2} a^{2} E
$$

következik (5. ábra).

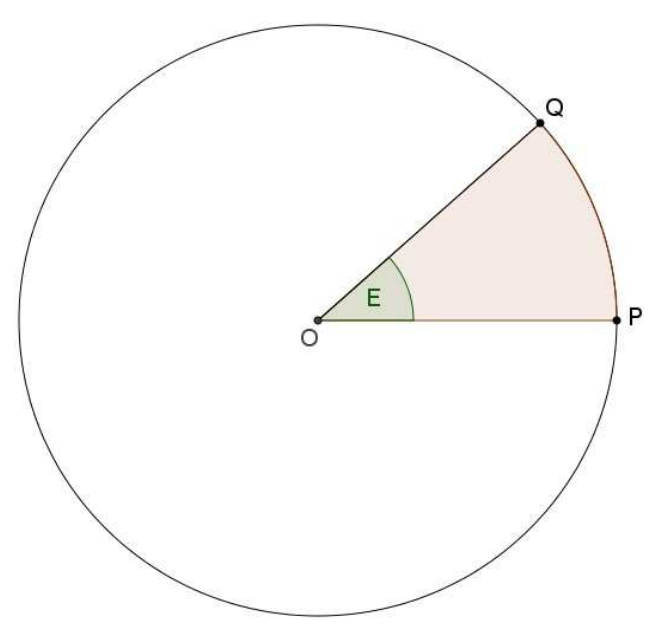

5. ábra: Az E szögű OPQ körcikk 
Az $O P_{1} Q$ háromszög területére pedig fennáll:

$$
t_{O P_{1} Q}=\frac{1}{2} c \cdot a \cdot \sin E=\frac{1}{2} e \cdot a^{2} \cdot \sin E,
$$

ahol $c=d\left(O P_{1}\right)$ a pályaellipszis lineáris excentricitása, továbbá $e=\frac{c}{a}$ jelenti az ellipszis numerikus excentricitását (6. ábra).

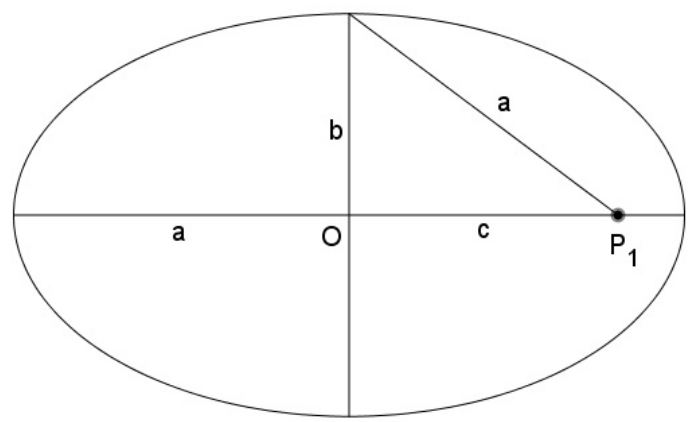

6. ábra. A pályaellipszis $a$ félnagytengelye, $b$ félkistengelye és $c$ lineáris excentricitása

Ekkor a $P_{1} P P_{2}$ ellipszisszektor területe (5), (6), (8) és (9) felhasználásával:

$$
t_{P_{1} P P_{2}}=\frac{b}{a} \cdot\left(\frac{1}{2} a^{2} \cdot E-\frac{1}{2} e \cdot a^{2} \cdot \sin E\right)=\frac{b}{a} \cdot \frac{a^{2}}{2}(E-e \sin E)=\frac{a \cdot b}{2}(E-e \sin E)
$$

adódik. Ekkor a (2), (3) és (10) összefüggések szerint viszont

$$
\frac{\frac{a \cdot b}{2} \cdot(E-e \cdot \sin E)}{a \cdot b \cdot \pi}=\frac{t-\tau}{T}
$$

következik, amelyből egyszerüsítéssel és átrendezéssel közvetlenül adódik a

Kepler-egyenlet.

$$
E-e \cdot \sin E=\frac{t-\tau}{T} \cdot(t-\tau)
$$

Maga Kepler e formula levezetése során a Szürakuszai Arkhimédesz (Kr. e. 287 - Kr. e. 212): A konoidokról és szferoidokról, valamint az Alexandriai Euklidesz (Kr.e. 365? - Kr.e. 300?) Elemek c. munkájára támaszkodott. Munkájának eredménye az Astronomia nova c. könyve 60. fejezetében olvasható.

A (12) összefüggésben szereplő

$$
n=\frac{2 \pi}{T}
$$

mennyiség a $P_{2}$ égitest közepes szögsebessége, ezt az égi mechanikában középmozgásnak nevezik. A (12) Kepler-egyenlet teljes jobb oldalán álló mennyiséget pedig

$$
M=\frac{2 \pi}{T}(t-\tau)
$$

középanomáliának mondják, ez az a szög, amelyet a $P_{2}$ égitest $t-\tau$ idő alatt leírna, ha $T$ sziderikus keringési ideje változatlan megmaradása mellett a fökörön egyenletesen mozogna. A (14) felhasználásával nyerjük a Kepler-egyenlet szokásos

$$
E-e \cdot \sin E=M
$$

tömör alakját, amelyből a többi mennyiség ismeretében a feladat az $E$ excentrikus anomália kiszámítása egy adott $t$ időpontban. 
Megjegyezzük, hogy a Kepler-egyenlet megoldásaként nyert $E$ excentrikus anomáliából a $v$ valódi anomáliát a

$$
\operatorname{tg} \frac{v}{2}=\sqrt{\frac{1+e}{1-e}} \cdot \operatorname{tg} \frac{E}{2}
$$

Gauss-féle képlet alapján számíthatjuk ki, amely képlet levezetése ÉRDI [1] munkájában megtalálható.

\section{A Kepler-egyenlet megoldása}

Mivel (15) Kepler-egyenlet transzcendens, így csak közelítő módszerekkel lehet megoldani. A továbbiakban egy grafikus megoldási módot mutatunk be, amelyet KöVESLIGETHY [2] ismertet részletesen.

Feladatunk tehát $M$ és $e$ ismeretében az excentrikus anomália közelítő $E$ értékének meghatározása (7. ábra).

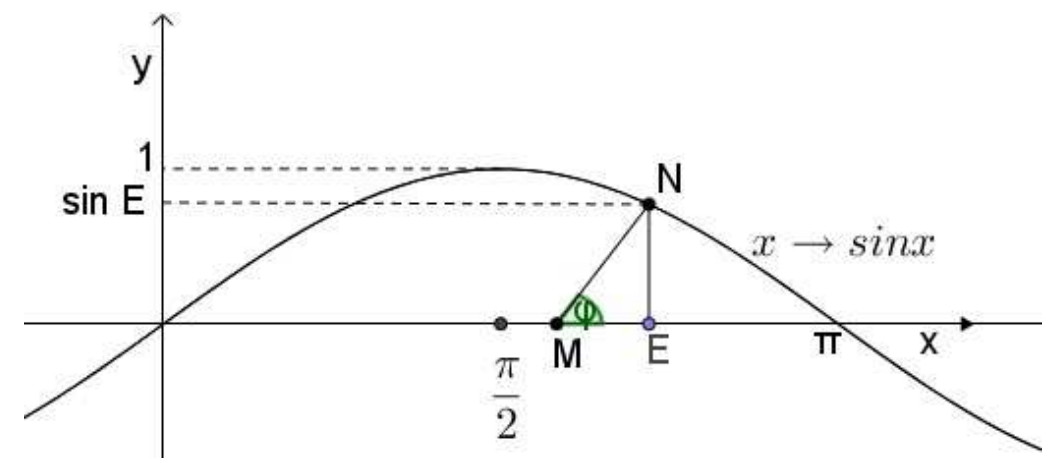

7. ábra. A Kepler-egyenlet közelítő grafikus megoldása

Első lépésként $t$ és $T$ birtokában (14) alapján kiszámítjuk $M$ értékét. Ezután megkeressük $M$ helyét a vízszintes tengelyen. Ezt követően mérünk fel az $M$ pontból kiindulva egy olyan $\varphi$ szöget, amelyre $\operatorname{ctg} \varphi=e$ teljesül. Az így kapott szögszár és az $x \mapsto \sin x$ görbéjének $N$ metszéspontját merőlegesen az $x$-tengelyre vetítve nyerjük az $E$ pontot. Valóban, az $M E N \Delta$ háromszögböl

$$
\frac{E-M}{\sin E}=\operatorname{ctg} \varphi=e
$$

adódik, amelynek átrendezésével

$$
E-M=e \cdot \sin E
$$

következik, ebből már közvetlenül adódik a (15) Kepler-egyenlet.

Ezzel megkaptuk $E$ közelítő értékét, amelynek egy pontosabb értékéhez is eljuthatunk, pl. a Newton-féle iterációs eljárással.

Tekintsük ugyanis az

$$
f(E):=E-e \cdot \sin E-M
$$

függvényt, amelynek $E$ szerinti első deriváltja

$$
f^{\prime}(E)=1-e \cdot \cos E
$$

alakú lesz. 


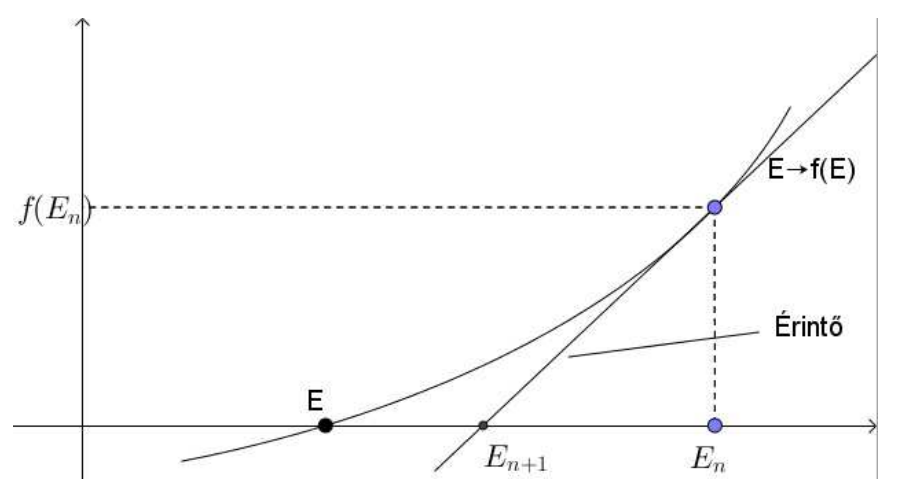

8. ábra. Az $E$ excentrikus anomália megközelítése a Newton-féle iterációs eljárással

A 8. ábra jelöléseivel ekkor az $f(E)$ görbe $E_{n}$ abszcisszájú pontjához tartozó érintőjére teljesül az

$$
\frac{f\left(E_{n}\right)}{E_{n}-E_{n+1}}=f^{\prime}\left(E_{n}\right)
$$

összefüggés, amelynek egyszerü átrendezésével adódik

$$
E_{n+1}=E_{n}-\frac{f\left(E_{n}\right)}{f^{\prime}\left(E_{n}\right)} \quad(n=0,1,2, \ldots),
$$

ha $E_{O}$ az előző lépésben bemutatott grafikus eljárással nyert közelítő értéke az $E$ excentrikus anomáliának.

A Naprendszer bolygóinál az $e$ numerikus excentricitás kicsi, de az eljárás nem csupán itt, hanem az elliptikus pályát jellemző teljes $0 \leq e<1$ intervallumon gyorsan konvergál a keresett $E$ értékhez.

A Kepler-egyenlet megoldása az egyik legnagyobb jelentőségü problémája a csillagászatnak. A Kepler-probléma megoldására számos eljárás született, ezeket részletesen tárgyalja ODELL-GOODING [3] munkája.

Sir Isaac Newton (1643-1727) munkái nyomán felismerték, hogy az általános tömegvonzás törvényére épülő 2-test probléma megoldása során az égi mechanikában az ellipszis pályák mellett felléphetnek parabola és hiperbola pályák is. Hiperbola pálya esetén pl. a (15) Kepler-egyenlet összefüggésével analóg formula

$$
e \cdot \operatorname{sh} H-H=M
$$

alakú, amelynek jelen dolgozatban tárgyaltakhoz hasonló elemi levezetésével a jövőben kívánunk foglalkozni.

\section{Köszönetnyilvánítás}

A szerző köszönetét fejezi ki Varga Enikő Erzsébet matematika-német szakos középiskolai tanárnőnek a cikkben szereplő ábraanyag gondos megszerkesztéséért.

\section{Irodalomjegyzék}

[1] Érdi, B., Égi mechanika I., Tankönyvkiadó, Budapest, (1977), p.319.

[2] Kövesligethy, R., A mathematikai és csillagászati földrajz kézikönyve, Kogutovicz és társa Magyar Földrajzi Intézete, Budapest, (1899), p.911.

[3] Odell, A. W. - Gooding, R. H., Procedures for Solving Kepler's Equation, Celestian Mechanics, 38. (1986), 307-334. http://dx.doi.org/10.1007/BF01238923

[4] Reiman, I., A geometria és határterületei, Gondolat, Budapest, (1986), p.419. 